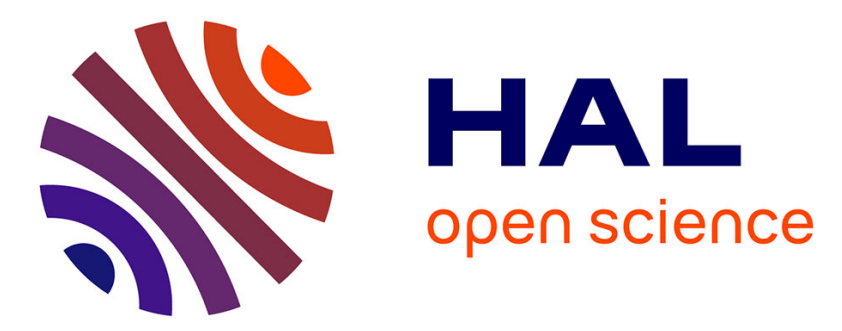

\title{
Urban artivism and migrations. Disrupting spatial and political segregation of migrants in European cities
}

\author{
Sarah Mekdjian
}

\section{To cite this version:}

Sarah Mekdjian. Urban artivism and migrations. Disrupting spatial and political segregation of migrants in European cities. Cities, 2017, 77, pp.39-48. 10.1016/j.cities.2017.05.008 . halshs-01541067

\section{HAL Id: halshs-01541067 \\ https://shs.hal.science/halshs-01541067}

Submitted on 23 Jun 2017

HAL is a multi-disciplinary open access archive for the deposit and dissemination of scientific research documents, whether they are published or not. The documents may come from teaching and research institutions in France or abroad, or from public or private research centers.
L'archive ouverte pluridisciplinaire HAL, est destinée au dépôt et à la diffusion de documents scientifiques de niveau recherche, publiés ou non, émanant des établissements d'enseignement et de recherche français ou étrangers, des laboratoires publics ou privés.

\section{(c)(1)}

Distributed under a Creative Commons Attribution| 4.0 International License 


\title{
Urban artivism and migrations. Disrupting spatial and political segregation of migrants in European cities
}

\author{
Sarah Mekdjian* \\ University Grenoble Alpes, PACTE Laboratory, France
}

\section{A R T I C L E I N F O}

\section{Keywords:}

Art

Artivism

Refugees

Migrations

Urban segregation

\begin{abstract}
A B S T R A C T
In the political context of the European "refugee crisis", what role does art, and in particular artivism, play in disrupting spatial and political segregation of migrants? Artivism -activism through art and by art- brings together very diverse forms of creations which share the political purpose of social change. In this article, I intend to present creative experiments which all bring into play questions of unequal political rights, in relation to migrants and citizens in European cities. First, I analyse the role that the urban space plays in contemporary artivism linked to migrations. Subsequently, I propose to lay out a corpus, which consists of an exploratory typology of artivist creations dealing with political rights in cities. Drawing on the analysis of several curatorial artivist platforms, I identify and document artivist creations (signs, architectural interventions, performances) that borrow from art, activism and social sciences, to disrupt urban and political segregation of migrants. The study concludes that artivist works may have a practical potential for political change and urban transformation, when they are ephemeral and "ordinary", disrupting the materiality and representations of everyday urban realities.
\end{abstract}

\section{Introduction}

In the political context of the European "refugee crisis", renewed nationalism and the criminalisation of international migration, what role does art and urban artivism, in particular, play in disrupting urban and political segregation of migrants? ${ }^{1}$ Precarious camps, slums, "jungles" (Agier, 2011) and squats are regularly built by migrants in European cities, and regularly displaced, destroyed and evicted by public authorities, while "migrant detention [mainly in urban detention centers] has developed constantly to become the preferred method of migrant population management in Europe and beyond since the 1990s" (Arbogast, 2016). If European civil societies as well as urban public authorities have also shown great abilities to innovate in the face of large-scale arrival of migrants, especially in Germany since 2011 (Katz, Noring, \& Garretts, 2016), xenophobia and urban segregation remain structural political problems. Artivism - activism through and by art
(Lemoine \& Ouardi, 2010; Lindgaard, 2005) - brings together diverse creations, whether they take the form of verbal or visual signs, graffiti, maps, installations or performances, that all have social change as their political purpose. According to Myriam Suchet, artivism "does not simply suggest new approaches to familiar urban situations and activities but rather enacts or operates new situations and new modes of actions. [...] The interval created by urban artivis[m] [...] must be understood, in both its temporal and spatial dimensions, as a delimited, ephemeral and disruptive event or space." (Suchet \& Mekdjian, 2016, 234). Thus, artivism can be understood as a critical process that destabilises everyday urban interactions and practices. In this article, I present several creative experiments whose modus operandi is the material transformation of urban situations and bringing into play questions of segregation and right of residence with respect to exiles, migrants and refugees. By presenting "some of the recent intersections of the political circumstances and aesthetic negotiations of geographical

\footnotetext{
* Domaine Universitaire-Bâtiment ARSH, UFR Sciences Humaines, Département de géographie sociale, 1281, avenue Centrale, 38400 Saint-Martin d'Hères, France

E-mail address: sarah.mekdjian@univ-grenoble-alpes.fr.

${ }^{1}$ The terms "migrants", "refugees", "asylum seekers", "exiles" are often used interchangeably, especially in the media. However they are not identical. The International Organization

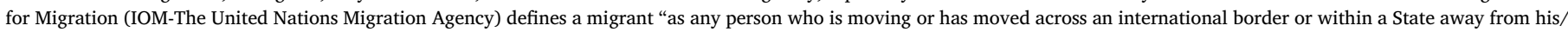

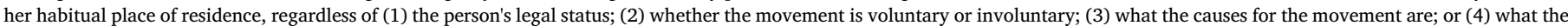

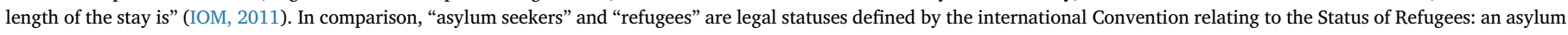

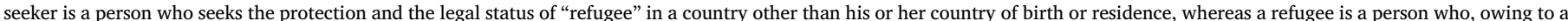

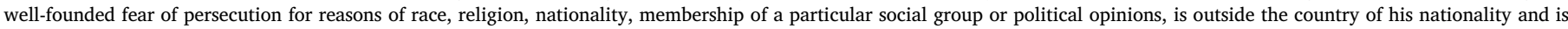

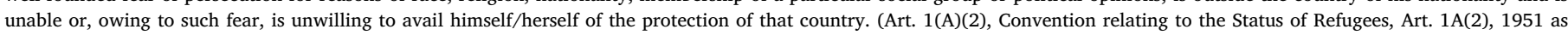

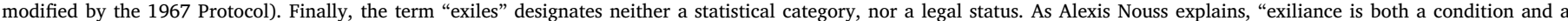
consciousness. [...] One could feel in exile without really being exiled or one could be exiled without feeling it" (Nuselovici (Nouss), 2015).
} 
mobility" (Demos, 2013, 4), art historian T.J. Demos lists various functions of artivism in the realm of migrations: "to discover innovative means to forge social bonds within transnational conditions that avoid sinking into regressive atavism or xenophobic hostility; to advance forms of life that reject the restrictive categories of identity and conventional modes of belonging; to direct the forces of mobility against the capture of commodification..." (ibid.). Amid such aesthetic and political intentions, what is the place of the city and of urban space? How can the city, an ambivalent space that both shelters and shuts in migrants, both a hostile and hospitable space, serve as a creative and subversive laboratory for artivism?

The notion of hostility refers implicitly to the notion of hospitality. While hostility and hospitality seem antinomic, philosopher Magali Bessone shows that their meanings are actually intertwined: to "host" foreigners "constitutes both a protection of the foreigners and a protection against them. [...] As their common etymological origin explains (hostire means "to make equal"), to "host" is a way to compensate for a positional or situational inequality established between two persons, one being at home, the other one being outside of his/her home. Welcoming the latter as an equal is a way to reduce the risk attached to his/her presumed non-belonging" (Bessone, 2015). In other words, to be hospitable implies to presuppose a clear distinction and inequality between "home" and "not home", "belonging" and "non-belonging". The foreigner is always supposed to represent a potential threat that needs to be controlled by welcoming him or her as an "equal". Therefore, hospitality presupposes an initial hostility towards foreigners considered as potential threats. Jacques Derrida also shows the ambivalence of "hospitality", by using the neologism of "hospitality": there is "no hospitality [...] without sovereignty of oneself over one's home, but since there is also no hospitality without finitude, sovereignty can only be exercised by filtering, choosing, and thus by excluding and doing violence" (Derrida \& Dufourmantelle, 2000, 79). Here Derrida explains the very contradiction (in his term "aporia") of the term "hospitality", consubstantial of "hostility" and "violence". While Derrida defines unconditional and unlimited hospitality ("the Law") as the fundamental principle of ethics, he explains that political hospitality ("the laws") can only be conditional, limited and somehow violent. Because of all these contradictions, Magali Bessone suggests to abandon the term "hospitality": as she explains, such a demanding ethical imperative and an ambivalent concept cannot help to frame good practices. She suggests instead focusing on "citizenship", as a political principle that should be based on the desire of participating to the collective conversation on political norms. Citizenship, she argues, should be distinguished from the question of belonging or not-belonging to a certain territory and therefore from the concept of "hospitality".

Following Bessone's argument, the main question here will not be to understand how artivism can help build hospitable cities but instead how artivism can help build cities which allow civic and political participation of all its users. In other words, we will question how artivism can help disrupt the spatial and political segregation of the "undesirables" (Agier, 2011) in European cities.

Without claiming to be exhaustive, this work identifies an exploratory typology of artivist interventions - works and performances that seek to disrupt urban segregation of migrants in Europe. The corpus is based on first-hand artivist experimentations made with people in exile in Grenoble (France) and second-hand information gathered from artivist projects created in France, Germany, Hungary and Sweden, these four countries and their main cities -Paris, Berlin, Budapest and Stockholm- offering contrasted exposure and political reactions to the arrivals of migrants since 2011. If the study focuses mainly on artivism in large cities, I included also Calais in northern France in the typology of works presented, as an archetypal place of spatial and political segregation of asylum seekers and refugees in Europe. Major refugee camps have been built in Calais since 2002 and were recently dismantled by the French authorities in October 2016.
The study could have included examples from the United Kingdom where artivist groups, some of them in relation with the situation of Calais, have created interesting works. The UK however is less exposed than the other countries selected for this study by the arrivals of asylum seekers: in 2015, the UK received 38,878 asylum applications (including dependents); this was less than Germany (431,000), Sweden $(163,000)$, Hungary $(163,000)$ and France $(50,900)$. The artivist works selected have all in common to be ephemeral; they were not created to last as objects or images in the materiality of the urban space. I argue that this particular relationship to space and time is a condition for potential political transformations.

First, I analyse the role that urban space and cities plays in contemporary artivism linked to migrations. Subsequently, I propose to lay out a corpus, which consists of an exploratory typology of artivist creations dealing with migrations and urban citizenship. Drawing on the analysis of several curatorial artivist platforms, I identify and document artivist creations (signs, architectural interventions, performances) that borrow from art, activism and social sciences, to oppose urban segregation -both spatial and political-. The study concludes that artivist works may have a practical potential for social change and urban transformation, when they are ephemeral and "ordinary", disrupting the materiality and representations of everyday urban realities.

\section{The role of urban space and cities in artivism linked with migrations}

Although cities are the first places of refuge for migrant populations, it appears that they have less visibility in artivist works linked to migration than borderlands (Amilhat Szary, 2012). International boundaries, especially the outermost borders of the European Union, as well as the United States-Mexico border in the desert, are the focus of many artivist interventions (ibid.). Borders are the hubs that make visible the national policies rejecting international migration. Walls, camps and surveillance systems are concentrated in these strategic places. A whole artivist field linked with borderlands (Amilhat Szary, 2012; Parizot et al., 2014; Schimanski \& Wolfe, 2010, 2017) seeks a subversion of biopolitics and the criminalisation of migration. In his work dealing with "the ways contemporary artists have reinvented documentary practices in their representations of mobile lives: refugees, migrants [and] the stateless" (Demos, 2013), art historian T.J. Demos builds up an important body of works and performances in which the city and everyday urban life are present but not the central objects of analysis. In his commentary on the exhibition "Out of Beirut", presented in 2006 at the Modern Art Oxford, the author evokes the importance of the urban landscape and of daily life in Beirut in order to reflect on the representation of migratory processes linked to the Lebanese Civil War (1975-1990). Urban space is mainly considered as a reflection of social processes rather than as a direct object of subversion. In the curatorial artivist platform of the antiAtlas of Borders collective, ${ }^{2}$ dealing with migrations and borders, few artworks deal specifically with cities and urban space, despite the fact that geopolitical borders are political, juridical and material discontinuities re-enacted in cities. For example, the artivist collective Hackitectura's counter-mapping (2004) depicts the Strait of Gibraltar and includes the surveillance systems aimed at restricting migrants from crossing but does not pay any particular attention to cities. Among the works that question the place of the city in

\footnotetext{
2 "The antiAtlas of Borders is an experimentation at the crossroads of research, art and practice. It was launched in 2011 at the Mediterranean Institute of Advanced Studies (Aix Marseille University), and has been co-produced by the Higher School of Art (Aix en Provence), PACTE laboratory (University of Grenoble-CNRS), Isabelle Arvers and La Compagnie. Since then, it has gathered researchers (social and hard scientists), artists (Web artists, tactical geographers, hackers, filmmakers, etc.) and professionals (customs, industry, military, etc.). The meeting between people from these different fields of knowledge and practice aims to create a radical shift of perspective in the way we apprehend both 21st-century borders and the boundaries separating fields of knowledge, art and practice." (http://www.antiatlas.net/en/. Accessed 17.11.2016).
} 
migrations and the processes of bordering/debordering (Van Houtum, Kramsch, \& Ziefhofer, 2004) in connection with urban space, Till Roskens's videography, Videomapping: Aïda, Palestine (2009), presents mental mappings as they are sketched by people living in the Aida Palestinian refugee camp in urban Bethlehem. The relationship with the daily spaces, lived and perceived, of the refugees in this camp, which over time have formed a self-contained city, is at the heart of Till Roskens's approach. In Francis Alÿs's work, entitled Sometimes doing something poetic can become political, and sometimes doing something political can become poetic (2004-2005), the daily geography of the city of Jerusalem is questioned on the basis of a rejection of the Green Line drawn in 1949 between Israel and the Arab states. Over a period of two days in 2004, Francis Alÿs travelled through Jerusalem on foot from the south to the north of the city while carrying cans filled with green paint with a hole drilled in them, which enabled him to retrace the border line on the ground in a way that is discrete but just as visible. "Alÿs restricted his walking to a 15-mile stretch through a divided Jerusalem, a hike that took him down streets, through yards and parks, and over rocky abandoned terrain. In a film of the walk made with Julien Devaux, he seems to attract little notice. People just go about their lives. Even Israeli soldiers at checkpoints barely acknowledge the lanky guy in jeans with a leaky can", comments American journalist Holland Cotter in 2007 in the New York Times (Cotter, 2007). The urban space of Jerusalem, its political divisions and the population displacements involved are questioned through this ephemeral performance.

\subsection{Explaining the under-representation of cities in artivist works dealing} with migrations: the hypothesis of methodological nationalism

As these artivist interventions suggest, cities are present in artivist and artistics works about migrations, but they remain often secondary to the sites of states' external borders or reduced to the status of décor. To explain these effects of the selective under-representation of cities, a hypothesis about methodological nationalism can be put forward. The central interest in borderlands, including at the heart of artivist works, could be explained by methodological nationalism that consists "in studying the social processes and actors by considering the national borders as the significant scale of analysis" (Von Busekist, 2013). By defining the notions of "borderities" and "mobile borders", Amilhat Szary and Giraut (2015) show how the classic linear and fixed topography of borders is more and more shifting to reticular, virtual and disseminated functions. "Borderities" are not to be found only at the edge of state territories but also within cities where the figure of the "stranger" is re-enacted through multiple urban sites of exclusion and segregation. Refugee camps in the city centers of Paris, Berlin, Prague or Belgrade are opening and facing violent evictions on a daily basis since 2014 and 2015. The centers of European cities as well as urban spaces more broadly are becoming major sites of bordering and debordering. Among the criticisms of methodological nationalism, which have been developed since the 1970s and are ongoing in the social sciences (Amelina, 2012; Smith, 1979; Wimmer \& Glick Schiller, 2002), cities thus appear as objects of study in which to reinvest in order to understand the various political processes of "inclusive exclusion" (Nyers, 2006), in particular of non-citizens. In 2016, one of the colloquia of the iNAME (Immigration and Methodological Nationalism, Sciences Po Paris, University of Paris Descartes) research programme ${ }^{3}$ pointed to urban studies as a potential tool to criticise methodological nationalism and understand the complexity of contemporary borderities. Usually applied in social sciences, the critics of methodological nationalism could also apply in contemporary art and artivism. If the city is a space where national territorial borders and norms are played out again and again, producing processes of social and juridical

\footnotetext{
${ }^{3}$ See http://www.sciencespo.fr/ceri/fr/content/nationalisme-methodologique-ettheories-politiques-de-limmigration-iname. Accessed 17.11.2016.
}

exclusion, it also offers the possibility of unprecedented political struggles where nationalism and segregation towards migrants could be challenged through the daily practices of the urban dwellers, whether they are migrants or not. The central hypothesis of this work is to view urban artivism as an increasing powerful lever of possible change for inclusive cities in Europe.

\section{An exploratory typology of urban artivist works opposing spatial and political segregations of migrants}

In the following section, I propose to lay out a corpus, which consists of an exploratory typology of artivist forms dealing with the stakes of urban segregation and citizenship, to then eventually consider their practical potential for social and urban transformation. This typology makes no claim to be exhaustive and is thought as an exploratory work in the making. The typology distinguishes several forms of urban artistic interventions: (1) signs: graffitis as ephemeral disruptive signs; -urban cartographies and counter-mapping; (2) architectural interventions: -ephemeral architectural interventions in the materiality of urban spaces; and (3) -urban artivist performances -carnavals; -subversive practices in the everyday urban life. All these forms have in common to engage with the temporal and spatial dimensions of cities to create ephemeral, and disruptive situations that call into questions the daily practices of urban life in relation with immigration.

\subsection{Graffitis as ephemeral disruptive signs}

Street art works, including graffiti and frescoes, among others, are among the most studied forms of urban artivism. As "a space for critical discourse" (Ulmer, 2016, 1), the street is used to express messages of solidarity with migrants and political slogans denouncing migratory policies. In a blog piece (Tulke, 2015) drawing on her academic work on street art and the aesthetic of crisis (Tulke, 2013), Julia Tulke identifies and analyses fifteen "pieces of street art and graffiti from Europe and beyond showing solidarity in the ongoing refugee crisis". Among the works that Tulke identifies, some were produced by artivist collectives, while others are anonymous or, on the contrary, signed by very famous artivists/artists. The two well-known artists of the German collective Herakut have produced frescoes (especially in Munich, Germany) that depict a maternal figure holding a child in her arms and are accompanied by the following text: "If we refuse refuge to those who seek it - what kind of people are we?" (Fig. 1).

This work echoes the anonymous graffiti placed on a train in Dresden, again in Germany, in 2015, which states in Arabic, "اهلًا وسهلًا" ("ahlan wa sahlan" - "a warm welcome" - Fig. 2), "perhaps the most spectacular graffiti action of the past weeks, especially considering the controversy [surrounding] racist attacks on refugees in the city", according to Tulke (2015).

These graffitis can be understood as the interruption of discursive and disruptive practices in the everyday urban landscape. Along with graffitis, counter-mapping of cities develop as a mode of critical thinking and acting, with the goal of creating urban practices that empower urban dwellers -citizens and non-citizens- to question their environment.

\subsection{Counter-mapping and artivist cartographic experiments}

Artivist mapping, also called critical or counter-mapping (Crampton, 2009; Dalton \& Mason-Deese, 2012), are multiplying more and more to produce alternative visual narratives of urban spaces. The creators of artivist mappings "use what Deleuze [1988] calls a 'new cartography,' a practice that creates new (political geographic) possibilities and other (political geographic) realities, rather than representing already existing geographies" (Dalton \& Mason-Deese, 2012, 443). Gilles Tiberghien traces the critical use of maps in art to the beginning of the modernist era and observes that, "with modernism, 


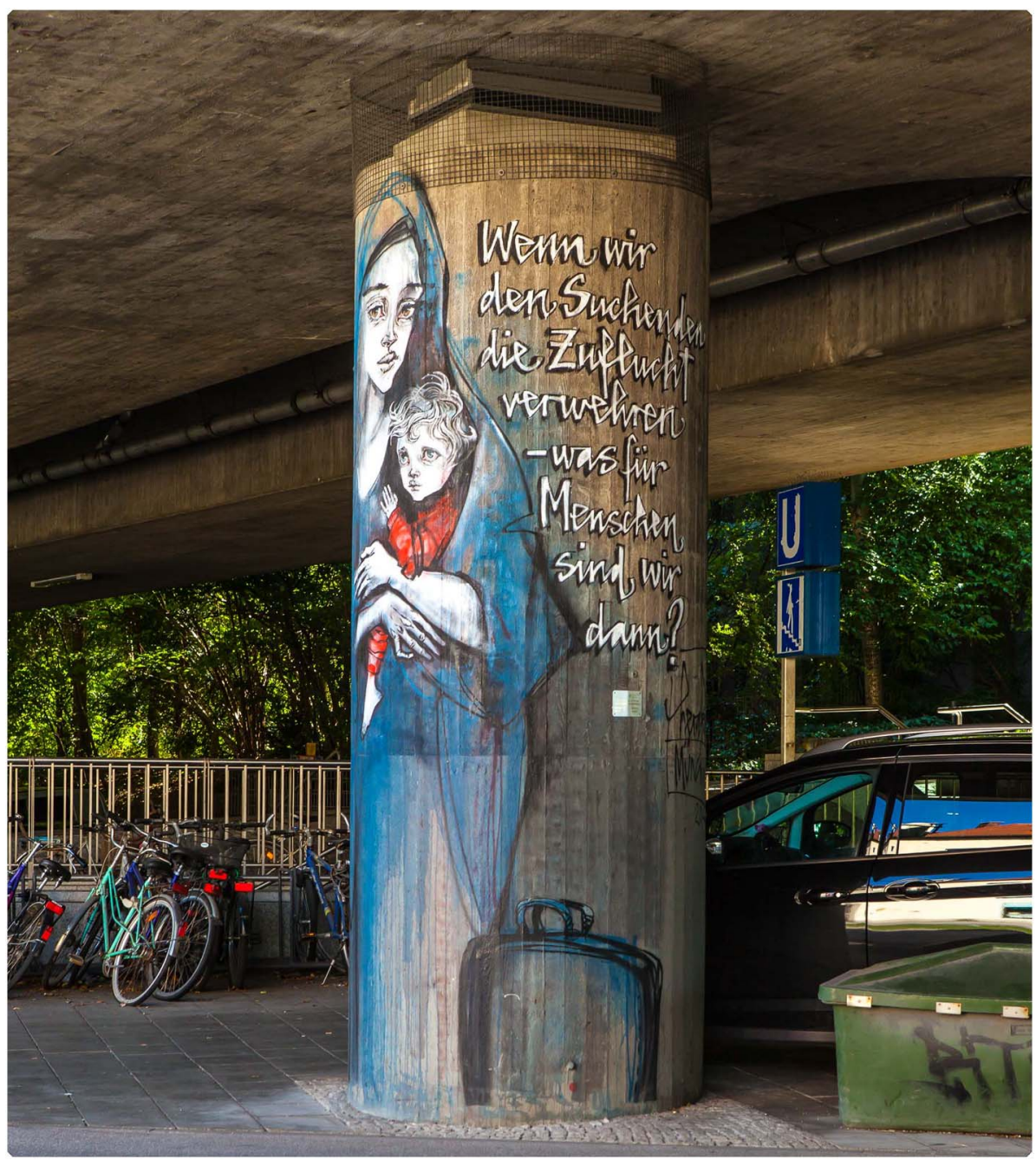

Fig. 1. Graffiti by Herakut, Munich, Germany, 2015, picture by http://munich-z.com/.

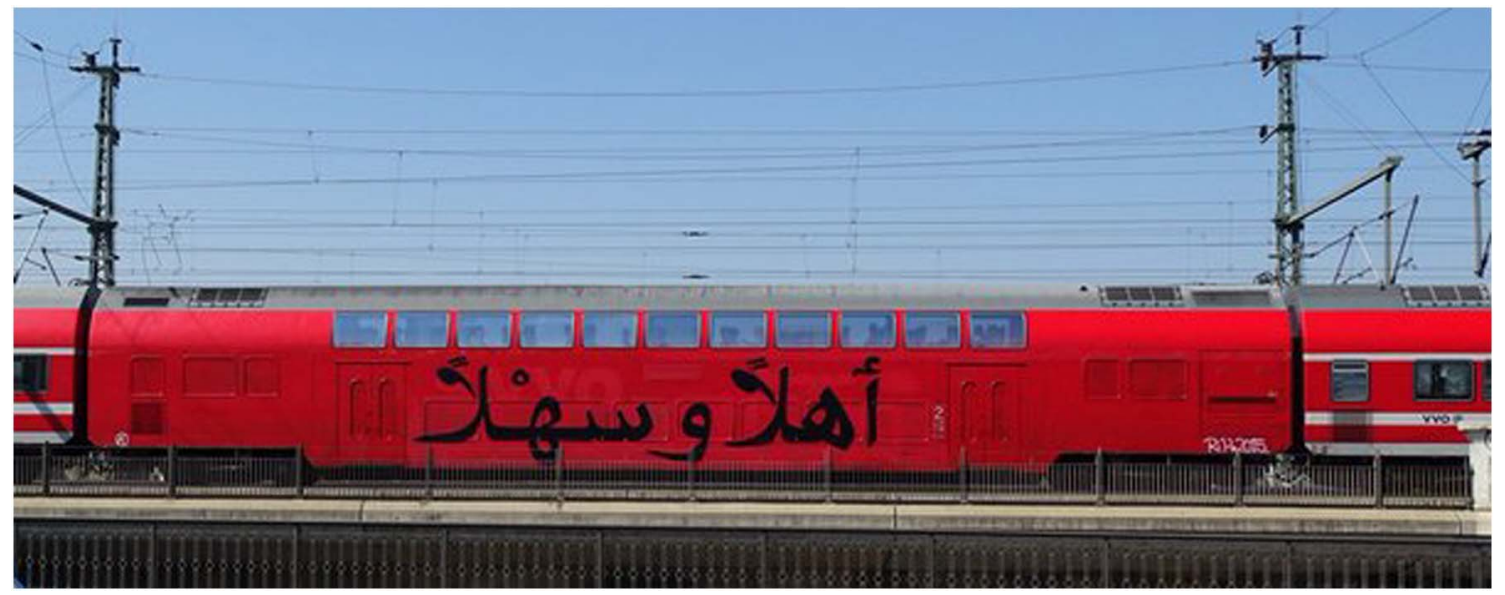

Fig. 2. "Ahlan wa sahlan" - "a warm welcome", anonymous graffiti, Dresden, Germany, 2015, picture by http://ilovegraffiti.de/.

conventionally starting with Manet, maps became an instrument of rupture, a critical mode in the regime of representation" (Tiberghien, 2010, 198). According to Tiberghien, "the map is based on an irreducible distance to its referent. Contemporary artists appropriate mapping practices not to bridge this gap but to circulate within it" (ibid.). The works of Marie Moreau, in particular Crossing Maps, produced in 2013, and Exquisite Geographies (2016), are inspired by these alternative and subversive uses of mapping. The work of Marie Moreau, a French artist who has worked with people in the situation of migration in Grenoble (France) for many years, lies somewhere between documentary and fiction. Moreau uses cartography as a tool to link up with migrants and collect their urban experiences, as well as a lever to transform urban spaces.

In Crossing Maps (2013), asylum seekers were invited to participate in a series of experimental, interactive mapping workshops in Grenoble that Marie Moreau and I organised (Mekdjian, 2016; Mekdjian \& Moreau, 2016). Over a two-month period, in May and June 2013, researchers, artists/performers, twelve inhabitants of Grenoble 
who were asylum seekers, a photographer and a research engineer met twice a week in a public community center. These workshops were intended to create encounters around mapping practices and to produce alternative narratives on contemporary migrations and urban space. Marie Moreau asked participants to make felt-pen drawings, cognitive mappings, of their urban experiences on large white sheets. On my side, I proposed a collaborative map key (using coloured stickers) based on words related to their migratory experience and life in Grenoble. Using this key, participants then integrated the stickers into their drawings. Participants had lived or travelled in many different countries, and their past and present nationalities included Sudanese, Eritrean, Armenian, Congolese, Guinean, Algerian, Azeri and Afghan. Some were asylum seekers or refugees, while others had no official administrative status. The participants, artists and researchers alike had to negotiate a range of linguistic, discursive, social and administrative differences. With the workshops' participants, faced with the daily challenge of adapting to an exclusionary city and country, we tried to invent and map out spaces that could function as resource-spaces, places of refuge/interstices. For Marie Moreau,

resource-spaces are also spaces that stimulate the imagination. [...] The maps create ruptures. New stories emerge in these spaces. Sometimes, from one conversation to the next, two completely different maps are created by the same hand. The map-makers, who use the maps to 'represent' (or represent themselves) use them for different reasons. They invent worlds that never existed before, worlds that don't exist in reality. The map represents and reconfigures a relationship to space in a given moment. It is a relative relationship that evolves (interview with Marie Moreau, 2012).

Among the maps produced in the workshops, a guide map of Grenoble was created by two participants (Figs. 3 and 4).

It is a tool intended to help newcomers arriving in Grenoble, settle in France and obtain social and political rights. Unlike a conventional guide that outlines pre-existing itineraries and points of reference, this map cannot be used to orient oneself in Grenoble. Neither the scale nor the points of interest can be verified in relation to the terrain represented. It calls for using one's imagination to explore the city shown on the map. The guide offers advices for general attitudes to adopt in the city, for example, "don't be afraid of police officers" (Fig. 2), and provides an itinerary that highlights several "resource sites" along the way (Fig. 1). When presented with the guide map, established residents of Grenoble experience disorientation and discover unknown places.

Exquisite geographies (2016), which visual and sound artists Marie Moreau and Julien Vadet developed in Grenoble, is another form of urban mapping artivism with people in exile. Moreau asked people in exile living in Grenoble to sketch and talk about their dream city. Julien Vadet recorded them. Based on these accounts, Moreau went to meet people who could help to turn certain aspects of the dream into reality. For example, a team of football players, most of them refugees, talked about a dreamed "sports city" where they could practise football without any difficulties. They explained that it was particularly difficult for them because all the fields in the city of Grenoble were reserved by teams registered at the City Hall, unlike their own informal team. After collecting this story, Moreau went to meet a person whose work it is to support the creation of local associations. The idea was to help the team of refugees form an association and thus gain access to the sports fields. When they met, Marie Moreau asked the person, who was a specialist in forming associations, to relate and map her own dream city. And so on. Thus, it is an exquisite corpse that relays the desire to connect the city dwellers -citizens and non-citizens- with each other. Exquisite geographies is conceived as a performative work: dreaming a desirable city, talking about it and mapping it can contribute to making it happen. The architectural and artivist interventions analysed in the following section are ephemeral attempts of building livable and politically emancipatory places-especially in refugee camps and shantytowns-.

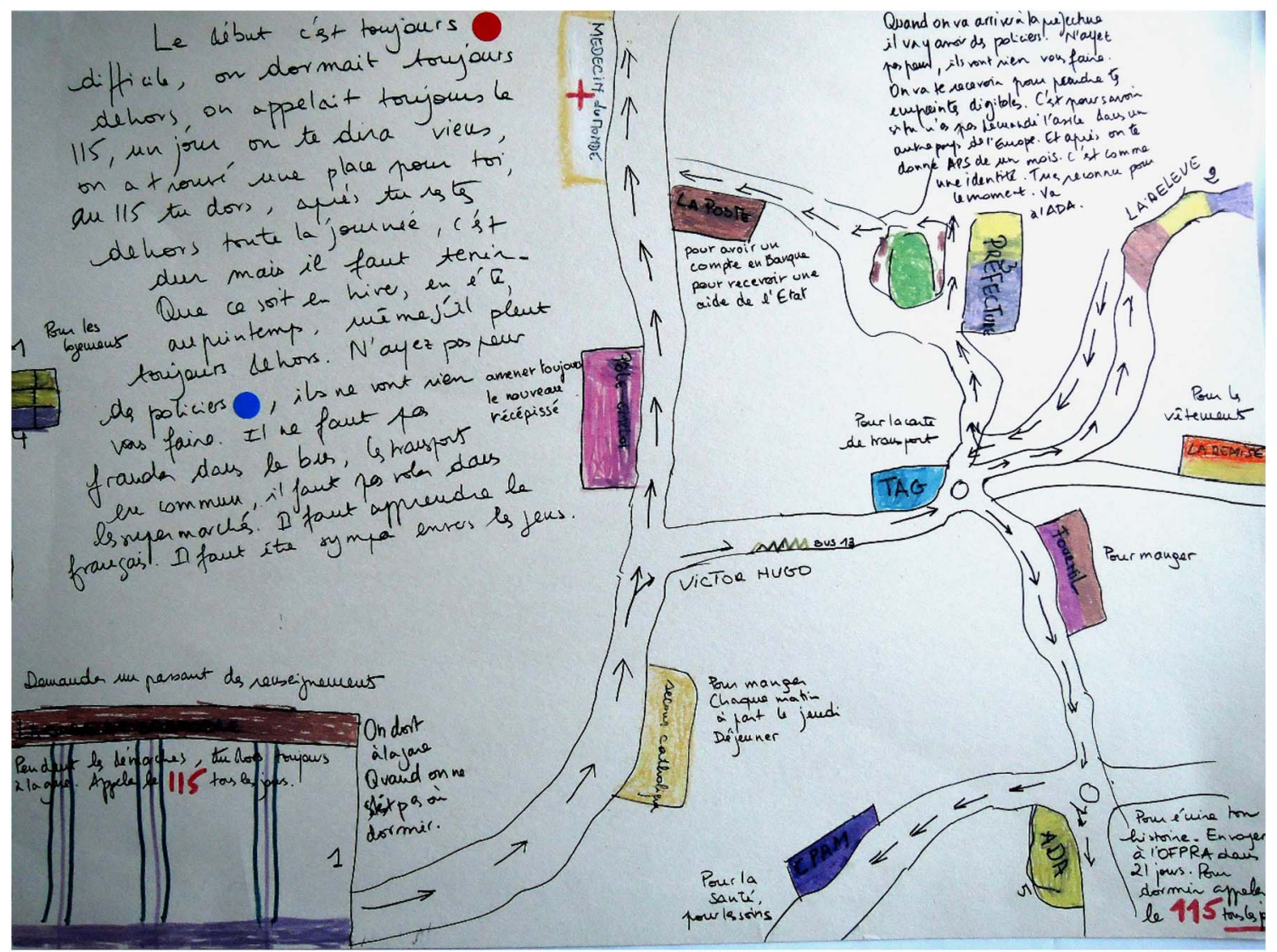

Fig. 3. Guide cartographique, collective work, Grenoble, France, 2013, picture by Mabeye Deme. 


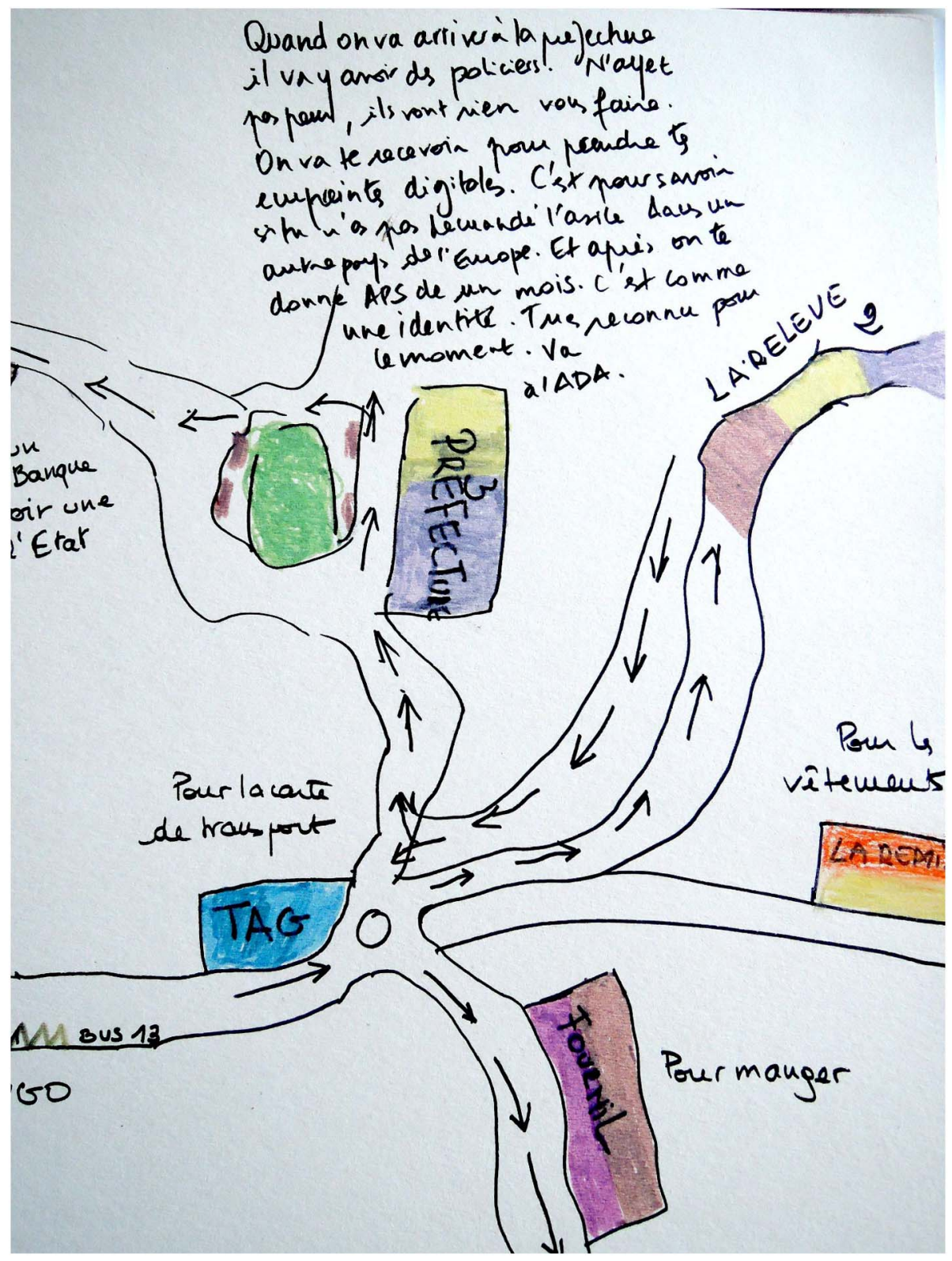

Fig. 4. Guide cartographique, details, collective work, Grenoble, France, 2013, picture by Mabeye Deme.

\subsection{Ephemeral architectural artivist interventions}

The PEROU collective (Pôle d'Exploration des RessOUrces Urbaines), ${ }^{4}$ created in France in 2012, defines itself as "a laboratory for research about the hostile city, created to articulate political and architectural action in response to the surrounding peril" (Thiéry, 2012). The artivist collective intends to promote the temporary forms of urban migrant camps and shantytowns by proposing ephemeral architectural interventions meant to improve the residents' living conditions. It brings together architects, urban planners, artists, activists, artivists, to intervene in different places of urban exclusion and segregation in France. Opposed to eviction and destruction of camps, PEROU argues for them to be recognised and legalised as emerging cities that need to be supported. Its interventions took place or are still taking place:

in the shantytowns of Ris-Orangis and Grigny; in Paris with a homeless collective to come up with experimental welcoming projects in the interstices of the capital; in Avignon with the Collective Action of Homeless People (Collectif d'Action des Sans Abri) to transform the

\footnotetext{
${ }^{4}$ See http://www.perou-paris.org/index.html. Accessed 17.11.2016.
}

brownfield of the former mail sorting office into an inhabited art center; in Arles in collaboration with Roma families to come up with other ways of living in a city by occupying the fringes; with eight research groups and eight photographers, PEROU worked also in Calais on the assumption that building is worth more than destroying in order to respond to the so-called 'migrant crisis' (Thiéry, 2016).

The collective worked in Calais's camp, i.e. "the Jungle", from 2015 until French public authorities tore it down at the end of October 2016. Calais, located in the north of France on the shore of the Strait of Dover, had several camps and shantytowns inhabited by migrants since the beginning of the 2000s. These camps and shantytowns were planned by the state and/or constructed spontaneously by the exiled people seeking to make it to England (Agier, 2011). One of PEROU's objectives was to valorise the exiled individuals' constructions considering the inhabitants of Calais "not [as] wanderers but [as] pioneers" (Thiéry, 2016). The work that PEROU performed consisted in identifying urban forms and their functions in Calais in order to valorise them and to organise workshops that would bring together residents, architects, urban planners, artists and activists to support the creation of a new city for the inhabitants, whether they are migrants or not. PEROU also 


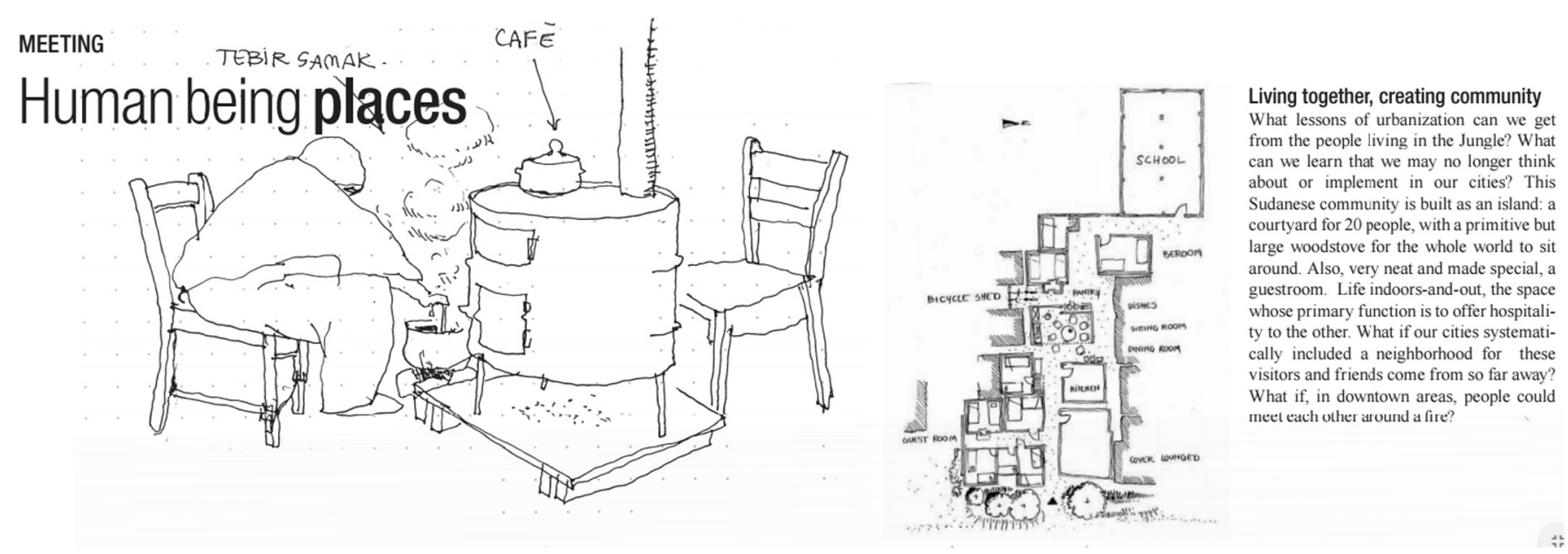

Fig. 5. Excerpt of the Calais Mag. Reinventing Calais, PEROU, April 2016.
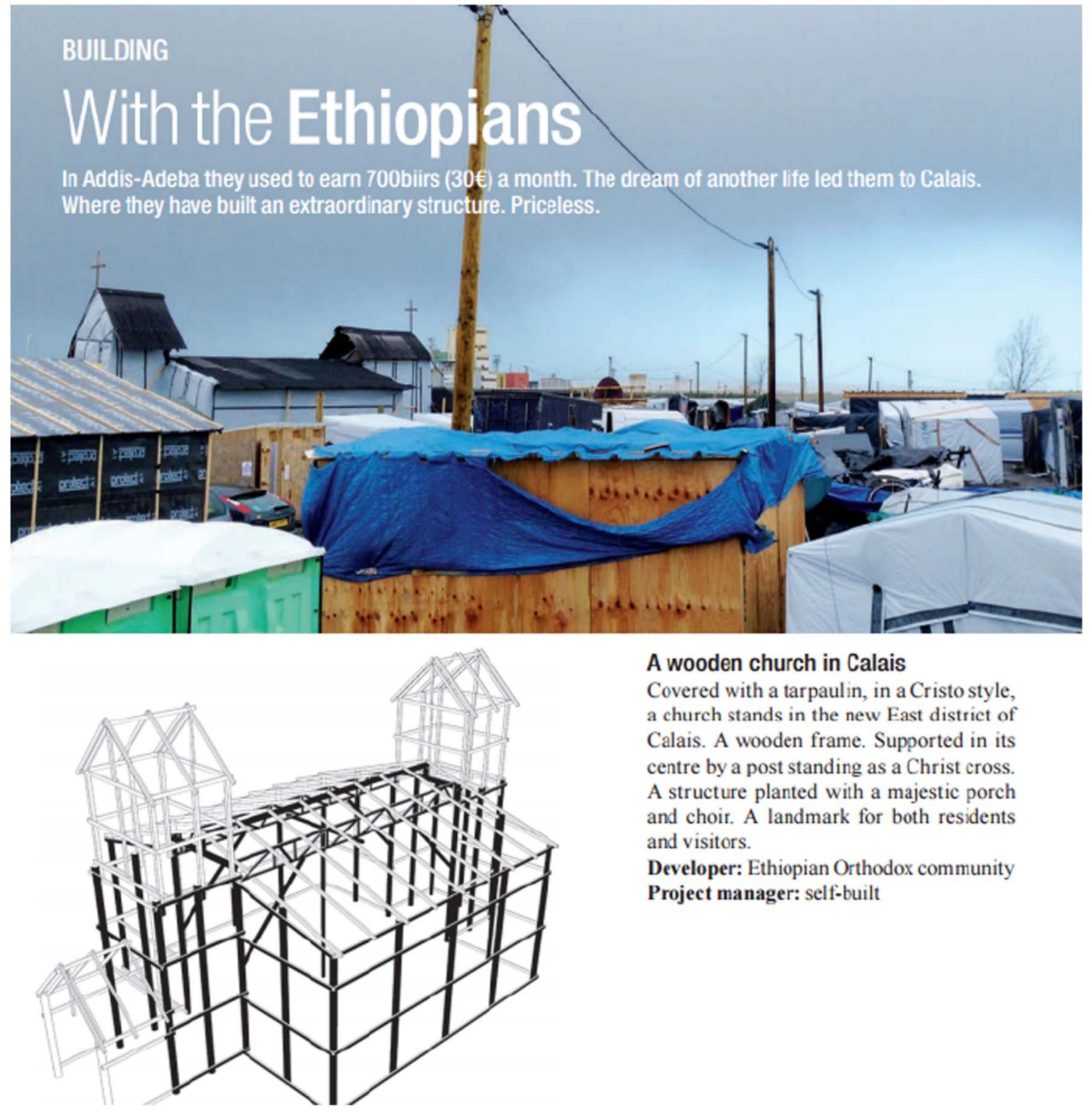

A wooden church in Calais

Covered with a tarpaul in, in a Cristo style, a church stands in the new East district of Calais. A wooden frame. Supported in its centre by a post standing as a Christ cross. A structure planted with a majestic porch and choir. A landmark for both residents and visitors.

Developer: Ethiopian Orthodox community

Project manager: self-built

Fig. 6. Excerpt of the Calais Mag. Reinventing Calais, PEROU, April 2016. 
produced and distributed documents concerning the urbanism of the "city" of exiles by criticizing the xenophobic, representations that dominated at the time (Figs. 5 and 6).

In April, we published a fake municipal magazine from the City of Calais and distributed 20,000 copies on the street. ${ }^{5}$ Developed in collaboration with the designer Malte Martin by using documents compiled by the eight teams of researchers and eight photographers with whom we coordinated the work since October 2015, this "Calais Mag" crept onto the public scene in order to tell a completely different story than the one that had been tossed around until then. It was not an artistic work inspired by the "problem of migrants" and produced to "raise public awareness" but rather an act of fiction projected into reality in order to upset the plans (Thiéry, 2016).

Between valorising that which exists and projecting that which could be, the work of PEROU is as much documentary as it is fictional. Although the exiles' "new city" in Calais was torn down at the end of October 2016, the PEROU collective intends to continue its work of valorising and recognising temporary urbanisms created by refugees, in contrast with the devalorisation and the public authorities' plans to systematically destroy or dilute. A similar statement on the need of valorising temporary urbanisms is shared by the "the Architecture for Refugees" collective, "an open source online and international platform -created in 2015 by architects Dennise Castillo, Henrik Ceccaroli, Zsófia Glatz and Bence Komlósi-. The platform collects and shares questions, problems, and ideas dealing with the architectural aspects of the current refugee crisis on the European and global scale". 6 The European "refugee crisis" and its consequences in Hungary in 2015 were the starting point of the platform:

We - the co-founders of 'Architecture for Refugees' - started dealing with the architectural aspects of the refugee crisis in September 2015 in Budapest, Hungary. At that time, thousands of refugees arrived to the capital city. The government and the local authorities assigned the "Keleti" railway station and the surrounding areas as a transit zone and this was the only action they actually took. They gave no further help or support to the fleeing masses. There was no top-down organised 'campsite', public infrastructure or shelters. The lack of organised and formal support forced the local people, groups and NGOs to take voluntary action. ${ }^{\text {? }}$

Most of the architectural projects presented on the platform have in common to consider that refugee camps may become, for some of them, "the cities of tomorrow" as much as refugee camps "remake cities". Therefore many architects and urban designers are trying to envision what kind of cities camps could and should become, outside the architecture of fear, control and segregation often developed by the states and humanitarian NGOs (Agier, 2011). In addition to the expression of disruptive signs and ephemeral architectural materialities, increasing performances and events disrupt the everyday temporal and spatial orders of cities.

\subsection{Urban artivist performances}

Since 2014, the Grande Parade Métèque ${ }^{8}$ in the Paris region has brought together artists, residents and activists for a festive wandering through various Parisian banlieues. ${ }^{9}$ Slogans of support for migrants are

\footnotetext{
${ }^{5}$ See http://www.perou-paris.org/pdf/Actions/CALAIS_16_mag_anglais_ONLINE.pdf. Accessed 17.11.2016

${ }^{6}$ See http://architectureforrefugees.com/. Accessed 17.11.2016.

${ }^{7}$ See and http://futurearchitectureplatform.org/news/38/the-story-of-architecturefor-refugees/. Accessed 17.11.2016

8 http://www.lagrandeparademeteque.org/. Accessed 17.11.2016

${ }^{9}$ In his book Badlands of the Republic, Mustafa Dikeç (2007), draws a political geography of the disadvantaged social housing neighborhoods of French banlieues. The term "banlieue" designates mainly these impoverished neighborhoods located in the peripheries of city centers, as Mustafa Dikeç explains: "The term banlieue has always had negative connotations (although there are many affluent banlieues). However, starting particularly with the 1990 s, there has been a strong stigmatisation of banlieues with
}

expressed by people walking in costume (Fig. 7). After the march, the people in the parade and the wider public collaborate on setting up a temporary village where conferences are held, stands for grass-roots organisations are put up, and music, circus and theatre performances touching on the themes of migratory policies and exile take place. Working on the political and insurrectional potential of the carnival, the organizers of the parade consider the urban space of the banlieues not as a margin, but as a central political and public stage for claiming equal political rights:

Six months prior to the start of the parade, we organise "Métèque cafés" in various public spaces: friendly places whose utopian goal is to produce our own knowledge. We have put in place artistic systems connected to this reflexivity in order to let our own words come forth, our sayings and our sensitive objects that can be exhibited on the day of the parade. Artisans and artists help to put up the constructions and costumes. [...] We know that this is a complex world and that the figure of the immigrant is a fantasy that is constructed and instrumentalised by the politics of fear. We know that continuously referring to this figure of immigrants, whether they naturalised or not, whether they are sons or daughters of immigrants or residents of the banlieues ... is unsustainable, and we have to move beyond that. We march with pride and to be visible in order to celebrate the good that comes from immigration (Activity Report of the Grande Parade Métèque, 2015).

It is also in this performative and transformational perspective that artist Núria Güell conceives of her artivist work. Several projects that she has developed are all about subverting the status of "migrants" or "refugees". In this way, Güell produces situations and performances in which these legal and administrative statuses are challenged: as she explains, her "work reformulates and deals with the limits of legality, analyses ethics practised by the institutions that govern us and detects abuses of power committed through the established legality and hegemonic morality. [...] Her artistic operations [...] are developed as disruptive tactics in specific contexts in order to subvert established power relations." 10

The Support Swedish Culture project, created in Sweden in 2014, dealt with begging in the city center and the status of Roma migrants associated with begging. Support Swedish Culture was a project that "aimed, by extending employment contracts, to employ four Roma people from Romania whose income came from begging on the streets of Sweden. Their role was to raise funds professionally in the public space, just as many NGOs do, but in this case to finance Swedish culture. Through these employment contracts, people would acquire rights and access to Swedish social services." ${ }^{11}$ This project was carried out in a political context where "in the 2014 European Parliament elections, the Sweden Democrats (SD, Sverigedemokraterna) based their campaign on throwing out Roma people from the streets of Sweden" (Ibid.). Thus, the main idea was to examine the different aspects of soliciting charitable donations in a public space such as a city street: when it is practised by Roma people and when it falls under the umbrella of large international humanitarian NGO fundraising campaigns. Turning Roma people into (remunerated by Güell through art institutions) professionals by means of fundraising, in this case for a fictional NGO that would preserve Swedish culture, was part of a subversive and ironic operation. This project sought to criticise the xenophobic urban policies targeting Romas in public space.

In a video ${ }^{12}$ and in the following text, Núria Güell explains how this project led to numerous conflicts and was eventually abandoned:

After several months of preparation, and once the contracts were signed, the art center that had commissioned the project unilaterally

\footnotetext{
(footnote continued)

reference to the formation of ghettos, ethnic separatism, and Islamic fundamentalism" (Dikeç, 2006, 161).

10 http://www.nuriaguell.net/. Accessed 17.11.2016.

11 http://www.nuriaguell.net/. Accessed 17.11.2016.

${ }^{12}$ See https://www.youtube.com/watch?v=v7GDaNFnTEk. Accessed 17.11.2016.
} 


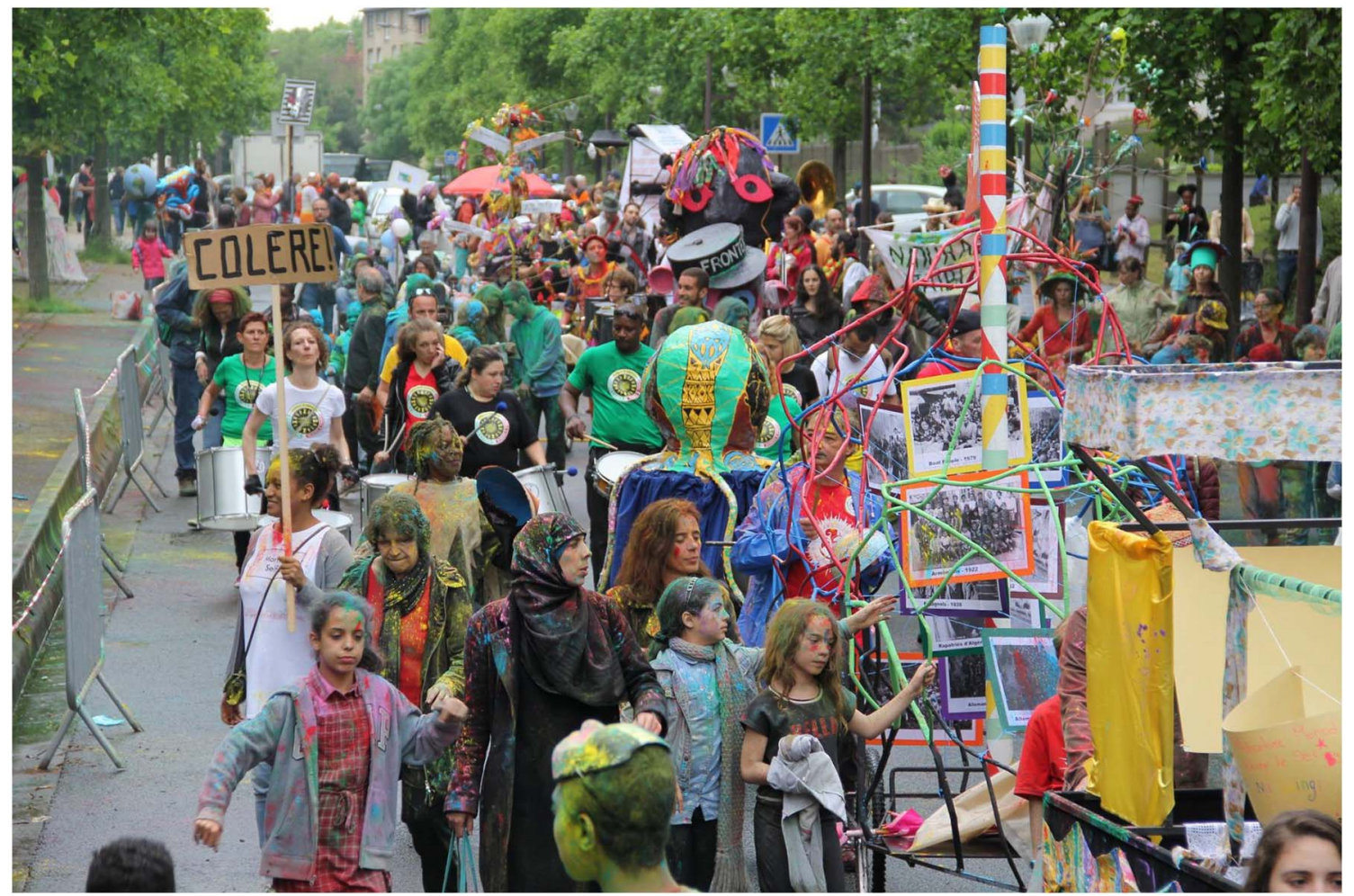

Fig. 7. La Grande Parade Métèque, 2016, picture by La Grande Parade Métèque.

decided to cancel it because of outrage from several leaders of other cultural institutions, who felt that the project used and exploited the Roma.

Although the contracts continued and salaries were paid out, the Romas who collaborated on the project disagreed with the cancellation, stating that if people in the art world said that they were being used it was because they assumed that because they were poor, they had no ability to think or make their own decisions. The four Romas also commented that, beyond the institutions' humanitarian intentions, the fact that they were being paid a salary for not participating was once again a way for them to be segregated, just as they usually are (Ibid.).

Although the project could not be undertaken, it led to several videos and installations being made to document the conflicts the project had sparked. The segregation organised by the urban public authorities - who regularly chase Romas engaged in begging out of the city center is supplemented here by a reticence on the part of art institutions to participate in such a subversive work. This project could have enabled the Roma participants to secure a salary and socio-political rights.

From graffiti to performance, including counter-mapping, these artivist interventions generate situations whose common feature is subversion, however transient, of the established urban order. In conclusion, I wish to point out what these interventions provide in terms of critical urban potential.

\section{Conclusion}

If artivist works dealing with migrations are often linked with the sites of geopolitical borders, they also take cities and urban spaces as playgrounds to create subversion and dissensus. While it is particularly difficult to circumscribe and define urban artivism because of the variety of forms that it takes and of its authors' intentions, all the works selected in our typology (signs, architectural interventions and urban performances) are based on concrete practices that are connected to the materiality of urban spaces -through direct interventions on the urban space (graffitis, ephemeral constructions) or through the performativity of representations and performances in the urban space (carnivals, counter-mapping, subversion of urban roles)-. I have deliberately excluded from the typology one of the most famous urban artivist work linked with migrations, Dismaland (2015), a "bemusement park" created by artivist Banksy in the seaside resort town of Weston-super-Mare in Somerset, England. Because it was created as an enclave in a decaying resort town, away from the places where refugees are actually trying to live, this temporary park participated more in a regeneration plan for Weston-super-Mare than in opposing urban segregation of migrants. In the works selected for the exploratory typology presented in this paper, criticism of spatial and political urban segregation is not produced from an abstract theoretical posture nor from enclaves separated from the actual places where refugees try to live: it is through practices and gestures - sketching, mapping, wandering, constructing that the urban everyday experiences of refugees and non-refugees tend to be transformed. Even mapping, which one can associate, by definition, with a commanding point of view over that which is mapped, is here connected to migrants' spatial and social everyday experiences. The Grenoble guide map, sketched by two people in exile for use by new arrivals, related a whole series of practical postures to adopt and very concrete routes to follow in the city. This guide map was completed based on its two authors' practical, day-to-day ordinary experiences of the city.

One of the main questions that still need to be considered concerns these interventions' transformational potential in the long term. "The power of these experiences can be partly attributed to their ephemeral nature, which is also their limitation", explains Myriam Suchet (Suchet \& Mekdjian, 2016, 235). "The interval created by urban artivism [...] must be understood, in both its temporal and spatial dimensions, as a delimited, ephemeral, and disruptive event or space" (Ibid.). In this limited spatial and temporal interval, the city and urban practices allow the possibility to other imaginaries and practices. The ephemeral is an integral part of how these interventions function; they aim not to install a new system but to constantly destabilise the established and the legitimate. The transformation at play in the studied interventions is different from the charity that is imposed, legitimised and stabilised by institutions and public authorities. What is at stake is 
an active political transformation meant to call into question the status of "migrants" as people who are "victims" and/or "deviants" and have to be "saved" and/or "normalised". Thus, desegregation comes from a series of ephemeral practices where the statuses (of migrants, inhabitants and residents) are questioned and where the urban spaces have been analysed at the level of the practices of exiled individuals who live, inhabit and cross them, often in a way that is precisely ephemeral and unstable. Because the urban artivist works are never completely stabilised, they can once again call urban norms into question, especially as they relate to the practices of city dwellers, whether they are migrants or not.

\section{References}

Agier, M. (2011). Managing the undesirables: Refugee camps and humanitarian government. Cambridge-Malden: Polity.

Amelina, A. (Ed.), (2012). Beyond methodological nationalism. Research methodologies for cross-border studies. New York: Routledge.

Amilhat Szary, A.-L. (2012). Border art and the politics of art display. Journal of Borderlands Studies, 27(2), 213-228.

Amilhat Szary, A.-L., \& Giraut, F. (Eds.), (2015). Borderities and the politics of contemporary mobile borders. Basingstoke, New York: Palgrave Macmillan.

Arbogast, L.. Migrant detention in the European Union: A thriving business. Migreurop, report. (2016). Retrieved from http://www.migreurop.org/IMG/pdf/migrant-detention-euen.pdf (Accessed 11. 04. 2017).

Bessone, M.. Le vocabulaire de l'hospitalité est-il républicain? Ethique publique 17 (1). (2015). Retrieved from http://ethiquepublique.revues.org/1745 (Accessed 11. 04. 2017) .

Cotter, H.. Thoughtful wanderings of a man with a can, New York Times, March 13th 2007. (2007). Retrieved from http://www.nytimes.com/2007/03/13/arts/design/13chan. html (Accessed 17.11.2016) .

Crampton, J. W. (2009). Cartography: Performative, participatory, political. Progress in Human Geography, 33(6), 840-848.

Dalton, C., \& Mason-Deese, L. (2012). Counter (mapping) actions: Mapping as militant research. ACME: An International E-Journal for Critical Geographies, 11(3), 439-466.

Demos, T. J. (2013). The migrant image: The art and politics of documentary during global crisis. Durham \& London: Duke University Press.

Derrida, J., \& Dufourmantelle, A. (2000). Of hospitality. Standford, California: Standford University Press.

Dikec, M. (2006). Guest editorial. Environment and Planning D: Society and Space, 24, $159-163$.

Dikeç, M. (2007). Badlands of the republic: Space, politics and urban policy. Malden-OxfordCarlton: Wiley-Blackwell.

International Organization for Migration. Glossary on migration. International migration law series 25. (2011). Retrieved from https://www.iom.int/key-migration-terms (Accessed 17.11.2016)

Katz, B., Noring, L., \& Garretts, N.. Cities and refugees: The German experience. Report, the centennial scholar initiative at Brookings. (2016). Retrieved from https://www. brookings.edu/wp-content/uploads/2016/09/cs_20160920_citiesrefugees_ germanexperience.pdf (Accessed 11.04.2017)

La Grande Parade Métèque. Activity report. (2015). Retrieved from https://drive.google.
com/file/d/OB6 uEfNDSRrddE1uem03OUZzTlU/view (Accessed 17.11.2016)

Lemoine, S., \& Ouardi, S. (2010). Artivisme. Art, Action Politique et Résistance Culturelle, Paris, Alternatives.

Lindgaard, J.. Artivisme. Vacarme 31. (2005). Retrieved from http://www.vacarme.org/ article1269.html (Accessed 17.11.2016)

Mekdjian, S. (2016). Les récits migratoires sont-ils encore possibles dans le domaine des Refugee Studies? Analyse critique et expérimentation de cartographies créatives. ACME: An International E-Journal for Critical Geographies, 15(1), Retrieved from https://www.acme-journal.org/index.php/acme/article/view/1211/1168 (Accessed 17.11.2016) .

Mekdjian, S., \& Moreau, M.. Re-drawing the experience: Art, science and migratory conditions. antiAtlas journal 1. (2016). Retrieved from https://www.antiatlas-journal.net/01-redrawing-the-experience-art-science-and-migratory-conditions/ (Accessed 17.11.2016) .

Moreau, M. (2012). nterview of the artist by Sarah Mekdjian. France: Grenoble.

Nuselovici (Nouss), A. (2015). La condition de l'exilé. Penser les migrations contemporaines. Paris: Maison des Sciences de l'Homme.

Nyers, P. (2006). Rethinking refugees: Beyond states of emergency. Routledge, Taylor and Francis Group: New York and London.

Parizot, C., Amilhat Szary, A.-L., Popescu, G., Arvers, I., Cantens, T., Cristofol, J., ... Vion, A. (2014). The antiAtlas manifesto. Journal of Borderlands Studies, 29(4), 503-512.

Schimanski, J., \& Wolfe, S. (2010). Cultural production and negotiation of borders: Introduction. Journal of Borderlands Studies, 25(1), 39-49.

Border aesthetics. In J. Schimanski, \& S. F. Wolfe (Eds.), Concepts and intersections. New York-Oxford: Berghahn.

Smith, A. D. (1979). Nationalism in the twentieth century. Oxford: Martin Robertson.

Suchet, M., \& Mekdjian, S. (2016). Artivism as a form of urban translation. An indisciplinary hypothesis. In S. Simon (Ed.), Speaking memory. How translation shapes city life (pp. 220-248). Montreal: McGill-Queen's University Press.

Thiéry, S.. Manifeste du PEROU-Pôle d'Exploration des Ressources Urbaines. (2012). Retrieved from http://www.perou-paris.org/Manifeste.html (Accessed 17.11.2016)

Thiéry, S. (2016). Considérant ce qui s'affirme. Multitudes, 3(64), 71-80.

Tiberghien, G. (2010). Poétique et rhétorique de la carte dans l'art contemporain. L'Espace géographique, 39(3), 197-210.

Tulke, J. (2013). Aesthetics of crisis. Political street art in Athens in the context of the crisis. Master of Arts (M.A.) im Fach Europäische Ethnologie, Berlin, Humboldt Universität zu Berlin. Retrieved from https://www.academia.edu/7746061/ Aesthetics of Crisis. Political Street Art in Athens in the Context of the Crisis 2013 .

Tulke, J.. 15 pieces of street art and graffiti from Europe and beyond showing solidarity in the ongoing refugee crisis. (2015). Retrieved from http://aestheticsofcrisis.org/2015/15pieces-of-street-art-and-graffiti-from-europe-and-beyond-showing-solidarity-in-theongoing-refugee-crisis/ (Accessed 17.11.2016) .

Ulmer, J. B. (2016). Writing urban space. Street art, democracy, and photographic cartography. Cultural Studies $\leftrightarrow$ Critical Methodologies, 16, 1-12.

Van Houtum, H., Kramsch, O., \& Ziefhofer, W. (Eds.), (2004). Bordering space. London: Ashgate Publishing Limited.

Von Busekist, A. (2013). Nationalisme méthodologique et théories politiques de l'immigration. Presentation of iNAME, a Research Project, Paris, Sciences Po. Retrieved from http://www.sciencespo.fr/ceri/fr/content/nationalisme-methodologique-ettheories-politiques-de-limmigration-iname.

Wimmer, A., \& Glick Schiller, N. (2002). Methodological nationalism and the study of migration. European Journal of Sociology, 43(2), 217-240. 